\title{
Co-movements between public and private wages in the EU: what factors and with what policy implications?
}

\author{
Benedicta Marzinotto ${ }^{1 *}$ (D) and Alessandro Turrini ${ }^{2}$
}

\author{
* Correspondence: \\ benedicta.marzinotto@uniud.it \\ ${ }^{1}$ Department of Economics and \\ Statistics, University of Udine, Via \\ Tomadini 30/A, 33100 Udine, Italy \\ Full list of author information is \\ available at the end of the article
}

\begin{abstract}
This paper assesses the relationship between public and private wages in the EU, as measured by general government and manufacturing compensations, respectively.

We find that the long-run relation between the two is stronger when the government is a large employer. Manufacturing compensations are better aligned with productivity and unemployment when general government compensations, to which they generally respond, are set through bargaining. Finally, manufacturing compensations react in the same way whether those in the general government sector are increased or cut, a relation that seems to hold also under fiscal consolidation provided the government is a large employer.
\end{abstract}

JEL Classification: C32, E24, E62, H59

Keywords: General government compensations, Wage setting, Cost competitiveness, Fiscal consolidation, Co-integration

\section{Introduction}

The Euro debt crisis has revived interest in the relation between fiscal policy and the labour market. Vulnerable countries face the multiple challenge of fixing distressed public finances, whilst having to improve cost competitiveness so as to reduce external imbalances as well as reabsorb excessive unemployment. These objectives are generally hard to reconcile, especially in high-debt countries where, for example, a fall in prices would come with a rise in real debt levels. Under specific circumstances, though, a fiscal consolidation strategy based on cutting excessive government wage expenditures could support cost competitiveness and possibly employment in the traded sector, if changes in public wages spill over to the private traded sector. This very same transmission channel is evoked in the fiscal-adjustment literature that has tried to quantify the differentiated output effects of consolidations based on their composition (Perotti 1996; Alesina and Perotti 1997; Lane and Perotti 1998; Alesina et al 2002; Ardagna 2004). ${ }^{1}$ In parallel and more generally, a growing body of research has been looking at the long- and short-run relation between government wages and the labour market in "normal" times broadly finding that the two wages are indeed inter-related (Afonso and Gomes 2014; Giordano et al 2011; Perez and Sanchez-Fuentes 2011; Lamo, Perez and Schuknecht 2012, 2013).

(C) The Author(s). 2017 Open Access This article is distributed under the terms of the Creative Commons Attribution 4.0 International License (http://creativecommons.org/licenses/by/4.0/), which permits unrestricted use, distribution, and reproduction in any medium, provided you give appropriate credit to the original author(s) and the source, provide a link to the Creative Commons license, and indicate if changes were made. 
This paper assesses the relationship between public and private wages, as measured by general government and manufacturing nominal compensations, respectively, on a sample of 17 European Union (EU) countries from 1980 to 2013 applying dynamic ordinary least squares (DOLS) to panel data for the long-run and an error correction model (ECM) for the short run. We focus specifically on the spill over of government to manufacturing compensations so as to address the question of the possible effects of certain fiscal policy measures on cost competitiveness via the supply side. Moreover, attention is devoted to the manufacturing sector because much of the literature on wage leadership is indeed concerned with the signalling that comes from wage bargainers in the manufacturing sector. Our estimation strategy aims at determining the strength of the relation between sectoral compensations across government sectors of different size, at assessing whether the way in which government compensations are set has any impact on the nature of the interaction with the private traded sector, and finally at establishing whether such relation is symmetric holding both when government compensations are increased and when cut and whether periods of large cuts (or fiscal consolidations) make a difference. Whilst our focus is on the relation going from general government to manufacturing compensations, we nonetheless also assess interactions in the opposite direction as a way of validating our results.

From a policy perspective, that government compensations spill over to the private sector is a non-trivial question. First of all, the strength and the persistence of the spill over says something about the supply-side effects of aggregate demand management, allowing for a more sophisticated modelling of the overall economic impact of government spending. More to the point, the issue is especially relevant in the euro area context where countries have lost the ability to recoup cost competitiveness by means of devaluation but have scope to decide on the composition, efficiency and equity of their government spending. Finally, our research provides an indication of the relevance of wage setting modalities in the public sector. A bargained model seems more efficient on the supply side but surely a definitive answer requires additional research on the most satisfactory trade-off between efficiency, equity and the need to achieve budgetary targets.

We add to the existing literature in three important respects. First, we explicitly consider the role of government sector size and estimate whether government compensations exercise a stronger impact on the labour market when the government is a large than when it is a small employer. This would mostly allude to an explicit market mechanism, an issue that has been only tangentially treated in the existing literature. Second, we account for wage setting modalities in the government sector distinguishing between compensations set by government decision and those set through collective bargaining. Whilst largely ignored by the literature, the latter seems like a crucial issue because it is an indication of the extent to which changes in government compensations are the result of exogenous fiscal policy decisions or rather part of the broader economy-wide wage setting system. Third, we provide some evidence on whether the spillover from the government to the private tradable sector is symmetric and whether periods of fiscal consolidation make a difference.

We find that general government compensations exercise a long-term impact on manufacturing compensations that is stronger for large public sectors. The long-run sector-size effect disappears when looking at real compensations, independently of 
whether government compensations rise or fall. This may be alluding to the fact that the long-run relation is crucially affected by second-round effects via inflation. By contrast, in the short-run, there is no size effect, with each $1 \%$ increase (fall) in government nominal compensations leading on average to $0.25 \%$ increase (fall) in manufacturing compensations, independently of whether the general government is a large or a small employer, a coefficient that is consistent with results from other studies (Afonso and Gomes 2014).

Having classified countries based on the prevailing public wage setting mode, we find that the size of the spill over from the government to the tradable sector is not affected by public wage setting neither in the long nor in the short run, but manufacturing compensations are better aligned with productivity and more responsive to unemployment when government compensations, to which private sector compensations respond, are set via bargaining. This result may allude to the fact that any bargaining process is "closer to the market" than unilateral government decision and hence closer to what might happen in the private tradable sector.

We further look at whether the relationship between general government and manufacturing compensations is symmetric. We use an asymmetric ECM as in Granger and Lee (1989) to verify whether the null hypothesis of symmetry is rejected against an alternative of asymmetry. We find evidence of symmetry, with a change in real government compensations leading to the same labour market effect independently of whether the change consists of a rise or a fall in real government compensations. Moreover, it appears that government wage consumption and the labour market tend to be decoupled under fiscal stress, unless the government sector is a relatively large employer.

The rest of the paper is structured as follows. Section 1 reviews the literature on the relation between, first, fiscal policy and competitiveness and, second, more generally, on the public-private wage link. Section 2 describes our sample and empirical strategy. Section 3 discusses the results. Section 4 looks at asymmetries and at the role of fiscal consolidation episodes. Section 5 concludes.

\subsection{The public-private wage link in the literature}

There is a well-established literature on the relationship between changes in government wage expenditures, competitiveness and external positions. Lane and Perotti (1998) show that a rise in government wage consumption reduces traded sector output via a rise in private sector wages, which would lead to a deterioration in the current account, if there exist adjustment costs that prevent consumption and investment of traded goods from falling rapidly. ${ }^{2}$ Lane and Perotti (2003) find further evidence that higher government wage spending impacts on the supply side by raising the real product wage, thereby depressing profitability. ${ }^{3}$ To the extent that a rise in public compensations is financed with resources drawn from the private sector that may take the form of increased labour taxes, the literature on the impact of labour taxes on private sector costs is equally relevant. So, for example, Alesina and Perotti (1997) look specifically at the effects of changes in labour taxes on unit labour costs and find that in a bargaining model higher labour taxes increase unit labour costs, unless wage negotiations are conducted by a monopoly union that is large enough to internalise the consequences of higher output prices on real consumption and employment. 
Focusing on dynamics around fiscal consolidation episodes, Alesina et al. (2002) and Ardagna (2004) argue that fiscal adjustments based on a reduction in the government wage bill induce a fall in real wages also in the private sector, thereby improving profitability and investment. Along similar lines, Barrios and Langedijk (2010) show that the downsizing of the government wage bill leads to more successful fiscal consolidation specifically under fixed exchange rate regimes, where the internal adjustment relies only on costs and prices, a result that is particularly relevant in the euro area context.

More generally, there is a growing body of research that has looked at the long- and short-run relationship between public and private wages in "normal" times, whether at stake is co-movement, interaction or a clear causal link going from one sector to the other, when for example, one of them is a wage leader. This research is less specific about the origin of changes in public/private wages and mainly devoted to understanding how different sectoral wages relate one to the other using a variety of statistical techniques ranging from co-integration and error correction models to vector autoregressive (VAR) systems or both.

Afonso and Gomes (2014) test the relationship between real general government and private wages on a panel of 18 OECD countries using a simple 2SLS estimation and allowing for an error correction term. Their analysis is mostly about the interaction between public and private wages and provides only indirect evidence on causality. They find that the interaction goes both ways and that each $1 \%$ increase in real public sector wage growth raises private sector real wage growth by $0.3 \%$. Lamo et al. (2007, 2012, 2013) use different statistical techniques to analyse co-movement in the short-, medium- and long-term but include also a causality test. They find strong crosssectoral correlation between public and private wages, with coefficients as high as 0.8 . To test causality, they implement a standard Granger causality test in a VAR framework and find that generally private wages have a stronger impact on public wages than vice versa. More specifically, the public sector acts as a wage leader only in the Netherlands and plays an important role, though not as far as leading, in Greece, Italy, Portugal and Finland. Finally, they juxtapose cross-country heterogeneity in coefficients to institutional settings and find that the role of the public sector is stronger, the greater the government's involvement in collective bargaining, the larger the public sector and the lower the competition from outside. Perez and Sanchez-Fuentes (2011) analyse the short-term relation between public and private wages in a VAR framework and find evidence of signalling especially by the private sector including early on during actual wage negotiations.

These studies are generally not explicit about the exact transmission channel from one sector to the other and tend to capture different dynamics that are at play at the same time. Results can be interpreted more easily if one or more potential transmission channels are first identified and then modelled in the empirical analysis. This is one of the specific objectives of the present paper. We identify below potential market-driven and institutional channels, stressing which ones would be more relevant for the interaction going from the government to the private sector and which ones matter for movements in the opposite direction. Subsequently, we propose a simple method for testing empirically the strength of the market channel as well as of one specific institutional channel. 
As concerns the possibility of changes in public wages impacting on the private sector, various channels may operate. First, large swings in public wages alter the supply of labour available to the labour market, inducing a change in the equilibrium wage if the labour market is perfectly competitive and in the absence of impediments to mobility. This is likely to be always true in the long-run with the two wages expected to be co-integrated with a slope coefficient of one. Second, rising public wages may crowd out private employment, increasing average productivity and thus wages in the private sector (Algan et al. 2002). Third, changes in public wages affect the outside option of unionized private sector workers, putting pressures on the bargaining process (Afonso and Gomes 2014), even when public and private employment remain separate. Fourth, changes in public wages that are compensated by an adjustment in labour taxation would mechanically alter private labour costs (Holmlund 1993; Forni and Giordano 2003). Indirectly, they may even alter wage demands if the wage bargaining system is such that wage setters have no incentive to internalise the consequences of their actions-i.e. where there is no centralization in wage bargaining (Alesina and Perotti 1997).

Similar albeit not identical transmission channels may be identified for the potential spill over going in the opposite direction, namely from the private to the public sector. First, wage bargaining in the private sector can have demonstration effects, whether it is the same union negotiating both wages or whether there are two different unions (Maffezzoli 2001; Ardagna 2007). Confirming this hypothesis, Perez and Sanchez-Fuentes (2011) find evidence of signalling by the private sector already in the negotiation phase for France and Germany in the period before 1999. Second, numerous EU countries have wage bargaining practices that grant wage leadership to the private sector. This is the case of the so-called Scandinavian wage determination model, with the exposed sector acting as leader or pattern setter for all other sectors including the government (see also Holm-Hadulla et al. 2010). Third, established practices can make public wages responsive to private ones. For example, in the Netherlands, there is a formal rule imposing that the growth rate of private wages is automatically applied to public sector wages (Hartog and Oosterbeek 1993).

We propose to isolate any market-driven mechanism by accounting for governmentsector size, where the assumption is that the larger the role of the general government sector as an employer, the stronger the impact on the labour market via both prices and quantities. The underlying assumption is that in the long-run, there is no impediment to cross-sectoral mobility that could create a disconnect between government and traded sector compensations. When it comes to institutional channels, however, we expect much greater cross-country heterogeneity, which complicates the exercise of finding a common testable hypothesis. Wage-setting practices would formally or informally grant wage leadership to one or the other sector, where the most common practice is that the exposed sector acts as a pattern setter for the rest of the economy. The reverse situation where private sector compensations follow those in government sector is less common. Would that happen, the possible institutional channels of transmission are imitation effects inducing private sector unions to follow public sector unions or fairness effects for which an "all-sector" union tends to negotiate similar 
increases for their affiliates in different sectors. Against these possibilities, though, a crucial dimension is likely to be the nature of public wage setting, namely whether general government compensations are set by government decision or by collective bargaining, with the institutional transmission channels described above operating in the case of bargaining only. Our strategy is thus to distinguish between compensations set by the government itself and those agreed through collective bargaining. That way, we should be able to isolate the operation of the institutional transmission channels and possibly differentiate them from alternative more market-driven channels.

\section{Data and empirical strategy}

For the public sector, we use general government compensations from the OECD Economic Outlook constructed by dividing general government final wage consumption expenditures (CGW) by general government employees (EG). ${ }^{4}$ Figures on general government are drawn from the System of National Accounts (SNA) and refer to public offices at all levels of government, non-market publicly owned hospitals, schools and social security organizations. We obtain comparable data for a sample of $17 \mathrm{EU}$ countries over $1980-2013 .{ }^{5}$ We approximate the traded sector by manufacturing.

In the long-run, nominal compensations in the two sectors should be cointegrated with a slope coefficient of one. To systematically analyse long- and short-run effects of general government compensations on the manufacturing sector, a co-integration approach is developed in a panel-data setting linking manufacturing compensations to a number of determinants, including compensations in the general government sector. The long-run relation is estimated in levels using dynamic ordinary least squares (DOLS), whilst the error correction mechanism (ECM) representation allows estimating the short-run relation between compensation growth, shocks in explanatory variables and the deviation from the dynamic long-run relation.

The long-run wage (compensation) equation should be interpreted as an equilibrium relation and is specified as:

$$
\ln w_{i t}=\alpha_{i}+\beta_{1} \ln w p_{i t}+\beta_{2} \operatorname{lnpr}_{i t}+\beta_{3} u_{i t}+\beta_{4} \ln c p i_{i t}+\varepsilon_{i t}
$$

where $i$ and $t$ are the index country and time, respectively, $w$ denotes the level of nominal compensation per employee in the manufacturing sector, $w p$ is the level of nominal compensation per general government employee, $p r$ is the real value added per person employed in the manufacturing sector, $u$ is the unemployment rate, cpi is the consumer price index, and $\varepsilon$ is the error term. All variables are in logs except for the unemployment rate. Compensations in the manufacturing sector are expected to be positively related to government compensations, prices and labour productivity and negatively related to unemployment. Co-integration is tested using DOLS with one lag and one lead for each regressor. We include country fixed effects not only to control for time-invariant country-specific factors but also because some variables are expressed as index numbers and would thus not be comparable across countries unless they are transformed. 
Given Eq. (1), the short-run (error-correction) wage (compensation) equation is specified as follows:

$$
\Delta \ln w_{i t}=\delta_{i}+\theta_{1} \Delta \ln w p_{i t}+\theta_{2} \Delta \ln p r_{i t}+\theta_{3} \Delta u_{i t}+\theta_{4} \Delta \operatorname{lncpi} i_{i t}+\gamma \hat{e}_{i t-1}+\varepsilon_{i t}
$$

where $\hat{e}$ is the lagged error correction term and all other variables except unemployment are expressed in log changes. A significant and negatively signed error correction term is taken as evidence of co-integration between government and manufacturing compensations; its coefficient captures the speed of adjustment back to equilibrium (see Table 6 in the Appendix).

\section{Results}

\subsection{The long-run effects of government sector size}

Table 1 shows the results of the long-run (column 1) and short-run (error-correction) wage equation (column 2) estimated on the whole sample. With the exception of the

Table 1 Long-run and short-run relation between manufacturing and general government compensations per employee, EU countries 1980-2013

\begin{tabular}{|c|c|c|}
\hline & $(1)$ & $(2)$ \\
\hline & Dynamic long-run relation & Error correction model \\
\hline \multicolumn{3}{|c|}{$\begin{array}{l}\text { Dependent variable: log of manufacturing compensation per employee, level (long-run relation) and } \\
\text { change (ECM) }\end{array}$} \\
\hline \multirow[t]{2}{*}{$\Delta$ log government compensations p.e. } & & $0.249^{* * *}$ \\
\hline & & {$[7.117]$} \\
\hline \multirow[t]{2}{*}{$\Delta$ log productivity in manufacturing } & & $0.188^{* * *}$ \\
\hline & & {$[5.426]$} \\
\hline \multirow[t]{2}{*}{$\Delta$ unemployment rate } & & $-0.00162^{*}$ \\
\hline & & {$[-1.578]$} \\
\hline \multirow[t]{2}{*}{$\Delta \log$ consumer price index } & & $0.693^{* * *}$ \\
\hline & & [19.51] \\
\hline \multirow[t]{2}{*}{ Log of consumer price index } & $0.687^{* * *}$ & \\
\hline & {$[9.410]$} & \\
\hline \multirow[t]{2}{*}{ Log of government compensations p.e. } & $0.435^{* * *}$ & \\
\hline & [7.968] & \\
\hline \multirow[t]{2}{*}{ Log of productivity in manufacturing } & $0.209^{* * *}$ & \\
\hline & {$[9.004]$} & \\
\hline \multirow[t]{2}{*}{ Unemployment rate } & $0.0057^{* * *}$ & \\
\hline & {$[3.421]$} & \\
\hline \multirow[t]{2}{*}{ Lagged error correction term } & & $-0.122^{* * *}$ \\
\hline & & {$[-3.140]$} \\
\hline \multirow[t]{2}{*}{ Constant } & $-1.087^{* * *}$ & $0.00715^{* * *}$ \\
\hline & {$[-7.009]$} & {$[3.273]$} \\
\hline Observations & 407 & 407 \\
\hline$R^{2}$ & 0.98 & 0.631 \\
\hline Number of countries & 17 & 17 \\
\hline
\end{tabular}

Estimation method: dynamic OLS with fixed effects and Newey West standard errors and ECM with standard errors robust with respect to heteroskedasticity and non-independence within country clusters. Sample: EU countries, except AT, BG, CY, DE, EL, HR, LT, LV, MT, RO and SI

Robust $t$-statistics: ${ }^{* * *} p<0.01 ;{ }^{* *} p<0.05 ;{ }^{*} p<0.1$ 
unemployment rate, all the variables exhibit the expected sign and are statistically significant. The ECM equation shows that deviations from the long-term relation are corrected over time, as indicated by the negative and significant coefficient of the error correction term, which is indeed supportive of co-integration amongst the variables. Moreover, the short-term response of manufacturing compensation growth has the expected sign for all the variables and is significant also for the unemployment rate. It is found that every $1 \%$ increase in general government compensations is associated, in the long-run, with a $0.4 \%$ increase in manufacturing compensations. ${ }^{6}$ Short-run effects are slightly weaker at almost $0.25 \%$. Our results are in line with those of analyses that have used similar estimation techniques (Afonso and Gomes 2014).

Our first hypothesis is that the relationship between nominal compensations in the government and those in the manufacturing sector is importantly conditioned by size, here measured by the ratio of general government to total employment. The greater the importance of the government sector as an employer, the more likely that changes to government compensations affect average conditions on the market and mostly so in the long-run when inter-sectoral mobility can be considered to be unconstrained. In order to test for the operation of this market-based channel, the EU sample is split in two groups: countries in which the average share of government to total employment is above the whole sample's median and countries where it is below the median. ${ }^{7}$ Table 2 provides results for the two groups. It is found that manufacturing and government compensations share a significant long-run relationship especially in large government sectors: for each $1 \%$ rise in government compensations, manufacturing compensations grow by $0.7 \%$ when the government is a large employer, but by only $0.2 \%$ when it is a small employer.

The relation goes both ways. When testing it in the other direction, namely from manufacturing to general government compensations, it is found that the long-run elasticity of government with respect to manufacturing compensations is of $0.8 \%$, thus much stronger than the $0.4 \%$ elasticity of manufacturing with respect to general government compensations. This confirms results from, for example, Lamo et al. (2007) (2012), where it is found that the private sector is more likely to have an impact on the public sector than vice versa, including in the long-run when covariates are accounted for. Secondly, in line with expectations, we find no difference between large and small government sectors; as a matter of fact, this dimension should be relevant only when it comes to assessing the impact of the public on the private traded sector. ${ }^{8}$

By splitting the sample in two groups, we are de facto assuming two completely separate regimes and hence isolate the size of the spill over for each of them. We do not expect that the size of the government sector has significant marginal effects on the inter-sectoral spill over but that after a certain threshold level, the spill over from one sector to another is more important. ${ }^{9}$ Still, as part of our robustness checks, we have also interacted government compensations with a dummy that captures above-median government sectors finding that the relationship between government and manufacturing compensations is indeed amplified when the government is an important employer. ${ }^{10}$ 
Table 2 Long-run and short-run relation between manufacturing and government compensations per employee, conditional on the size of the government sector, EU countries 1980-2013

\begin{tabular}{|c|c|c|c|c|}
\hline & (1) & (2) & (3) & (4) \\
\hline & \multicolumn{2}{|c|}{ Dynamic long-run relation } & \multicolumn{2}{|c|}{ Error correction model } \\
\hline & $\begin{array}{l}\text { Large government } \\
\text { sector }\end{array}$ & $\begin{array}{l}\text { Small government } \\
\text { sector }\end{array}$ & $\begin{array}{l}\text { Large government } \\
\text { sector }\end{array}$ & $\begin{array}{l}\text { Small government } \\
\text { sector }\end{array}$ \\
\hline \multicolumn{5}{|c|}{$\begin{array}{l}\text { Dependent variable: log of manufacturing compensation per employee, level (long-run relation) } \\
\text { and change (ECM) }\end{array}$} \\
\hline \multirow{2}{*}{$\begin{array}{l}\Delta \text { log government } \\
\text { compensations p.e. }\end{array}$} & & & $0.214^{* * *}$ & $0.288^{* * *}$ \\
\hline & & & {$[4.186]$} & {$[8.236]$} \\
\hline \multirow{2}{*}{$\begin{array}{l}\Delta \text { log productivity } \\
\text { in manufacturing }\end{array}$} & & & $0.193^{* * *}$ & $0.178^{* * *}$ \\
\hline & & & {$[4.037]$} & [3.411] \\
\hline \multirow[t]{2}{*}{$\Delta$ unemployment rate } & & & $-0.00193^{* *}$ & -0.00137 \\
\hline & & & {$[-2.456]$} & {$[-1.177]$} \\
\hline \multirow{2}{*}{$\begin{array}{l}\Delta \text { log consumer } \\
\text { price index }\end{array}$} & & & $0.638^{* * *}$ & $0.709^{* * *}$ \\
\hline & & & [9.429] & [17.90] \\
\hline \multirow{2}{*}{$\begin{array}{l}\text { Log of consumer } \\
\text { price index }\end{array}$} & $0.416^{* * *}$ & $0.938^{* * *}$ & & \\
\hline & {$[4.695]$} & [11.09] & & \\
\hline \multirow{2}{*}{$\begin{array}{l}\text { Log of government } \\
\text { compensations p.e. }\end{array}$} & $0.679^{* * *}$ & $0.204^{* * *}$ & & \\
\hline & {$[10.65]$} & {$[3.706]$} & & \\
\hline \multirow{2}{*}{$\begin{array}{l}\text { Log of productivity } \\
\text { in manufacturing }\end{array}$} & $0.172^{* * *}$ & $0.214^{* * *}$ & & \\
\hline & {$[5.724]$} & {$[5.181]$} & & \\
\hline \multirow[t]{2}{*}{ Unemployment rate } & $0.00983^{* * *}$ & 0.00318 & & \\
\hline & [5.592] & {$[1.436]$} & & \\
\hline \multirow{2}{*}{$\begin{array}{l}\text { Lagged error } \\
\text { correction term }\end{array}$} & & & $-0.176^{* *}$ & $-0.150^{* *}$ \\
\hline & & & {$[-3.022]$} & {$[-2.401]$} \\
\hline \multirow[t]{2}{*}{ Constant } & $-1.018^{* * *}$ & $-3.082^{* * *}$ & $0.0128^{* * *}$ & 0.00308 \\
\hline & {$[-6.271]$} & {$[-11.37]$} & {$[4.651]$} & [0.995] \\
\hline Observations & 193 & 214 & 193 & 214 \\
\hline$R^{2}$ & 0.9 & 0.991 & 0.514 & 0.740 \\
\hline Number of countries & 8 & 9 & 8 & 9 \\
\hline
\end{tabular}

Estimation method: dynamic OLS with fixed effects and Newey West standard errors and ECM with standard errors robust with respect to heteroskedasticity and non-independence within country clusters. Sample: EU countries, except AT, BG, CY, DE, EL, HR, LT, LV, MT, RO and SI

Robust $t$-statistics: ${ }^{* * *} p<0.01 ;{ }^{* *} p<0.05 ;{ }^{*} p<0.1$

\subsection{The role of public wage setting}

The second proposition we put to the test is that public wage setting may potentially have a bearing on the nature of the relationship between government and manufacturing compensations. We isolate two possible regimes, one which wages set by government decision and one where these are set through collective bargaining. In the case of the former, we would be mostly capturing the effects of a fiscal policy decision (or shock) on the labour market, which should be independent of whether the labour market is competitive or uncompetitive as discussed in Jackman et al. (1992). In the case of bargaining, the relation between public 
and private wages should rather reflect features of the wider wage setting system in each country. Here, high cross-country variation is more likely. In some countries, public and private wages are negotiated by the same union. In others, they are negotiated by different unions but each tends to imitate the other, for example, through envy effects (Maffezzoli 2001; Ardagna 2007). In some other countries, there is an explicit institutional mechanism in place that grants wage leadership to one or the other sector, resulting in high bargaining coordination. We limit ourselves to distinguishing between wages set unilaterally by the government and those agreed by the government together with employees' representatives in a bargaining framework against the assumption that, for example, mechanisms such as imitation or envy effects are present only in the case of bargained wages.

To test for the role of public wage-setting regimes, the sample is thus split in two groups: countries where government wage setting takes place via collective bargaining and where government wages are set by legislative decisions. Countries are classified based on the predominant wage determination regime. ${ }^{11}$ Table 3 displays the results.

Table 3 Long-run and short-run relation between manufacturing and government compensations per employee, conditional on government wage setting model, EU countries 1980-2013

\begin{tabular}{|c|c|c|c|c|}
\hline & (1) & $(2)$ & (3) & (4) \\
\hline & \multicolumn{2}{|c|}{ Dynamic long-run relation } & \multicolumn{2}{|c|}{ Error correction model } \\
\hline & Bargaining & Decision & Bargaining & Decision \\
\hline \multicolumn{5}{|c|}{ Dependent variable: manufacturing compensations, level and change (log) } \\
\hline \multirow[t]{2}{*}{$\Delta$ log government compensations p.e. } & & & $0.360^{* * *}$ & $0.215^{* * *}$ \\
\hline & & & {$[6.745]$} & {$[5.980]$} \\
\hline \multirow[t]{2}{*}{$\Delta$ log productivity in manufacturing } & & & $0.156^{* *}$ & $0.218^{* * *}$ \\
\hline & & & {$[3.324]$} & {$[4.935]$} \\
\hline \multirow[t]{2}{*}{$\Delta$ unemployment rate } & & & $-0.00210^{*}$ & -0.00155 \\
\hline & & & {$[-2.199]$} & {$[-1.405]$} \\
\hline \multirow[t]{2}{*}{$\Delta \log$ consumer price index } & & & $0.629^{* * *}$ & $0.705^{* * *}$ \\
\hline & & & [6.781] & {$[24.51]$} \\
\hline \multirow[t]{2}{*}{ Log of consumer price index } & $0.458^{* * *}$ & $0.705^{* * *}$ & & \\
\hline & {$[5.945]$} & {$[7.019]$} & & \\
\hline \multirow[t]{2}{*}{ Log of government compensations p.e. } & $0.528^{* * *}$ & $0.481^{* * *}$ & & \\
\hline & {$[9.669]$} & {$[5.083]$} & & \\
\hline \multirow[t]{2}{*}{ Log of productivity in manufacturing } & $0.241^{* * *}$ & $0.0941^{* *}$ & & \\
\hline & {$[11.28]$} & {$[2.191]$} & & \\
\hline \multirow[t]{2}{*}{ Unemployment rate } & $-0.00676^{* * *}$ & 0.00166 & & \\
\hline & {$[3.875]$} & {$[0.621]$} & & \\
\hline \multirow[t]{2}{*}{ Lagged error correction term } & & & $-0.146^{* * *}$ & $-0.142^{* *}$ \\
\hline & & & {$[-3.670]$} & {$[-2.891]$} \\
\hline \multirow[t]{2}{*}{ Constant } & $-0.753^{* * *}$ & $-2.367^{* * *}$ & $0.00593^{*}$ & $0.00639^{* *}$ \\
\hline & {$[-5.667]$} & {$[-6.757]$} & {$[1.905]$} & {$[2.456]$} \\
\hline Observations & 224 & 183 & 224 & 183 \\
\hline$R^{2}$ & 0.993 & 0.987 & 0.637 & 0.643 \\
\hline Number of countries & 8 & 9 & 8 & 9 \\
\hline
\end{tabular}

Estimation method: dynamic OLS with fixed effects and Newey West standard errors and ECM with standard errors robust with respect to heteroskedasticity and non-independence within country clusters. Sample: EU countries, except AT, BG, CY, DE, EL, HR, LT, LV, MT, RO and SI Robust t-statistics: ${ }^{* * *} p<0.01 ;{ }^{* *} p<0.05 ;{ }^{*} p<0.1$ 
Whilst there is no major difference across the two regimes in the short run, manufacturing compensations appear to be considerably less reactive to productivity and to unemployment over the long-run in countries where public wages are set by the government. This result could be linked to the fact that public sector wages set unilaterally by the government are less likely to reflect market forces weakening the link between manufacturing compensations, labour productivity and unemployment dynamics.

As above, we split the sample in two groups so as to assume that public wage-setting modalities produce two completely separate regimes. We have also here interacted government compensations with a dummy that captures bargaining regimes and obtained a result similar to the one obtained from the split sample with a significant interaction term that indicates a positive but quantitatively trivial difference in the size of the spill over when wages are bargaining compared to when they are set by government decision. ${ }^{12}$

\subsection{Fiscal consolidation and asymmetries}

Understanding the relationship between government wage consumption and the labour market is especially relevant in the current European context. Pre-crisis macroeconomic imbalances have been driven by prices and costs in the non-tradable sector spilling onto the exposed sector, especially in countries such as Ireland and Portugal (Blanchard 2007). In the bust, in almost all euro area countries under stress, fiscal consolidation plans rested on a reduction or freeze in the government wage bill, whether achieved via wage and/or employment cuts or freezes.

Fiscal consolidations are "extraordinary times". It is likely that under conditions of fiscal distress not only are wage setting practices in the government sector affected under a sense of urgency but it may also be that the interplay between government and private sector compensations is somehow altered. Table 4 displays correlations between nominal government compensation growth and manufacturing compensation growth under alternative fiscal conditions. ${ }^{13}$ This preliminary evidence suggests that government and manufacturing compensations are less closely correlated in periods where

Table 4 Correlation between government and manufacturing compensations' growth under alternative fiscal conditions, EU 1980-2013

\begin{tabular}{|c|c|}
\hline Consolidation & $0.40^{*}$ \\
\hline Non-consolidation & $0.82^{*}$ \\
\hline \multicolumn{2}{|l|}{ Consolidation } \\
\hline Large public employer & $0.81^{*}$ \\
\hline Small public employer & 0.20 \\
\hline \multicolumn{2}{|l|}{ Non-consolidation } \\
\hline Large public employer & $0.79^{*}$ \\
\hline Small public employer & $0.83^{*}$ \\
\hline \multicolumn{2}{|c|}{$\begin{array}{l}\text { Sample: EU countries (excluding AT, BG, CY, DE, EL, LT, LV, MT, RO, SI) over 1980-2012 (1995-2012 in the case of CZ, EE, } \\
\text { HU, SK). Fiscal consolidations are defined as a change in the structural balance of at least } 1.5 \% \text { of GDP in } 1 \text { year or of at } \\
\text { least } 3 \% \text { of GDP over a 3-year period, with at least } 0.5 \% \text { improvement in each year. For the years where structural balance } \\
\text { data are not available in the AMECO database, the primary cyclically adjusted budget balance is used. Countries are split } \\
\text { according to their government size on the basis of the average share of government to total employment (countries with an } \\
\text { average value above the median are classified with a large government sector). Source: OECD Economic Outlook } \\
\text { *Pearson correlation coefficients at least } p<0.05\end{array}$} \\
\hline
\end{tabular}


major consolidations take place. The interpretation may be that during consolidations, government wage consumption is mainly dictated by the objective of reducing government deficits and therefore less likely to co-move with the private traded sector. However, the evidence also shows that in countries with a relatively large government sector, the correlation remains strong also during episodes of fiscal consolidation.

The evidence presented above is but only suggestive. So as to derive more robust information about how different sectoral compensations relate to one another in good versus bad times, we introduce an asymmetric ECM as in Granger and Lee (1989) to determine whether the response of manufacturing compensations to changes in general government compensations is asymmetric, varying depending on whether government compensations are increased or cut. To do so, we use real instead of nominal compensations so as to have a sufficient number of negative values. We apply the same methodology as for previous specifications but split the error correction term into positive and negative values and run two separate (short-run) wage equations. The null hypothesis of symmetry would be rejected if the coefficients on the positive and negative values of the error correction term are significantly different. Table 5 presents the results. The coefficients on the positive and the negative values of the error correction term are not significantly different, which implies that a cut in real government compensations is transmitted to the labour market in the same way as an increase. ${ }^{14}$ We further split the group with negative values of the errors into large and small government sectors and find that, at least in normal times, the strength at which

Table 5 Asymmetric short-run relation between manufacturing and government compensations per employee, EU countries 1980-2013

\begin{tabular}{|c|c|c|c|c|}
\hline & $(1)$ & $(2)$ & (3) & (4) \\
\hline & \multicolumn{2}{|c|}{ Error correction model } & \multicolumn{2}{|l|}{ Error correction model (-) } \\
\hline & Positive & Negative & Large government sector & Small government sector \\
\hline \multicolumn{5}{|l|}{$\begin{array}{l}\text { Dependent variable: manufacturing } \\
\text { compensations, change (log) }\end{array}$} \\
\hline \multirow{2}{*}{$\begin{array}{l}\Delta \text { real government } \\
\text { compensations p.e. }\end{array}$} & $0.412^{* *}$ & $0.409^{* *}$ & $0.386^{*}$ & $0.413^{* *}$ \\
\hline & {$[7.392]$} & {$[6.114]$} & [3.078] & {$[7.143]$} \\
\hline \multirow[t]{2}{*}{$\Delta$ productivity in manufacturing } & $0.285^{* *}$ & $0.300^{* *}$ & $0.347^{* *}$ & 0.222 \\
\hline & {$[3.497]$} & {$[3.852]$} & {$[4.409]$} & {$[1.547]$} \\
\hline \multirow[t]{2}{*}{$\Delta$ unemployment rate } & $-0.00226^{*}$ & -0.00234 & $-0.00347^{*}$ & -0.000848 \\
\hline & {$[-2.205]$} & {$[-1.641]$} & {$[-2.414]$} & {$[-0.469]$} \\
\hline \multirow[t]{2}{*}{ Lagged error correction term (+) } & $-0.314^{* *}$ & & & \\
\hline & {$[-2.963]$} & & & \\
\hline \multirow[t]{2}{*}{ Lagged error correction term (-) } & & $-0.330^{* *}$ & $-0.253+$ & $-0.354^{* *}$ \\
\hline & & {$[-4.296]$} & {$[-2.257]$} & {$[-4.276]$} \\
\hline \multirow[t]{2}{*}{ Constant } & $0.0228^{* *}$ & $0.00974^{* *}$ & $0.0135^{* *}$ & 0.00825 \\
\hline & {$[5.549]$} & {$[4.193]$} & {$[5.669]$} & {$[1.826]$} \\
\hline Observations & 407 & 407 & 193 & 214 \\
\hline$R^{2}$ & 0.314 & 0.319 & 0.429 & 0.255 \\
\hline Number of countries & 17 & 17 & 8 & 9 \\
\hline
\end{tabular}


government compensation cuts spill over to the export sector is not conditional on the size of the public sector. ${ }^{15}$

\section{Conclusions}

We have found that there are significant inter-linkages between compensations in the general government and in the manufacturing sector both in the long and in the short run. The long-run relation between government and manufacturing compensations wages is much stronger when the government is a large employer, a result that appears to be driven mainly by second-round effects via inflation. The other important finding is that in countries where government wages are set by collective bargaining, manufacturing compensations tend to be better aligned with productivity and to be more responsive to unemployment, possibly because bargaining processes are generally closer to the market than unilateral government decisions. Finally, the reaction of manufacturing compensations to changes in government compensations is found to be symmetric. Such symmetry is unaffected by the size of the public sector. Nevertheless, under fiscal consolidation episodes, the two nominal compensations are correlated only when the government is a large employer, possibly alluding to the effect on prices and wages of some types of expenditure-based fiscal consolidations.

The linkages highlighted here are not meant to capture causality; nevertheless, they still offer some insights into understanding the possible labour market impact of changes in the government wage bill. Our evidence is suggestive of the fact that wagebill-based fiscal consolidations can affect the external sector leading to competitiveness improvements and possibly to an adjustment of macroeconomic imbalances. By contrast, our analysis is unfit to quantify the extent to which the composition of budget consolidation contributes to cushioning negative output effects of fiscal adjustment via the demand channel. One secondary implication is that the sequencing of fiscal consolidations in a monetary union should be set in such a way to allow each member state to fully benefit from potential supply-side effects via the labour market. Finally, we contribute to unpacking the effects of government wage consumption by accounting for the institutional setting against which public wages are set. Our evidence seems to suggest that bargaining is generally more efficient in terms of its effects on the labour market. Nevertheless, this is a new unexplored topic that would deserve greater attention and additional work so as to better capture the conditions for an optimal trade-off between efficiency, equity and the need to respect budgetary targets.

\section{Endnotes}

${ }^{1}$ In this paper, we are not concerned with output effects from fiscal consolidation strategies, but simply aim at verifying whether the evoked labour-market channel is actually operating, irrespective of its contribution to the size of fiscal multipliers.

${ }^{2} \mathrm{~A}$ strong assumption underpinning the analysis is that the domestic economy is too small to affect the demand for traded goods, which implies that the domestic traded sector is subject only to foreign demand and that fiscal policy shocks of this kind operate solely via the supply channel.

${ }^{3}$ However, it is found that the impact on quantities such as output and employment is smaller, which suggests a limited pass-through from costs to prices in the presence of positive fiscal shocks. 
${ }^{4}$ This is obviously an approximation of the average wage in the general government sector. Yet, disaggregation by type of occupation, hours worked as well as the public wage distribution relative to that of the private sector are not expected to interfere with our twofold research questions, i.e. whether public sector size and wage bargaining modes bear an impact on the interaction between public and private wages.

${ }^{5}$ The only exception is Ireland, where general government data include public enterprises.

${ }^{6}$ The multivariate setting possibly explains a coefficient that is significantly lower than one.

${ }^{7}$ The existing literature has analysed the issue of size only in a cursory fashion. For example, Lamo et al. $(2007,2012)$ include public sector size amongst the variables that may affect the odds of public wage leadership and find that the government is more likely to Granger-cause private wages when it is a large employer. We differ from their approach in two respects. First, we are merely concerned with the relation (or interaction) between the two wages not with leadership (or causality). Second, we go beyond probability analysis and quantify the spill over from the public to the export-oriented sector by estimating separate wage equations for large and small government sectors.

${ }^{8}$ Results of the response of government to manufacturing wage levels and growth rates are not shown. The estimated wage equation includes general government compensations per employee as dependent variable and, as regressors, compensations per employee in manufacturing, a proxy for labour productivity in the government sector, the consumer price index and the unemployment rate.

${ }^{9}$ Quantifying the exact size of this threshold level goes beyond the scope of the present paper.

${ }^{10}$ The results are available upon request.

${ }^{11}$ For a description of national public wage-setting systems, see European Commission (2014), p. 11. It should be noted though that the classification aims at capturing the predominant regime, whilst some countries have in fact hybrid systems, with, for example, the government setting wages by decree but only after extensive consultations with unions (e.g. Austria). It should be noted though that our sub-sample does not include obvious hybrid systems.

${ }^{12}$ The results are available upon request.

${ }^{13}$ By convention, episodes of fiscal consolidation are defined as those where the structural primary balance improves by at least $1.5 \%$ of GDP in 1 year or at least $3 \%$ in 3 years, with a minimum of $0.5 \%$ improvement in each year. Such a definition permits to isolate both cases of "cold shower" consolidation episodes and more gradual consolidation episodes.

${ }^{14}$ This is generally true also in the normal ECM. When running estimations (1) and (2) on real instead of nominal compensations, we do not obtain significantly different results except for the fact that there is no public sector size effect neither in the long nor in the short run, which may allude to the fact that the long-term elasticity of manufacturing to government wages is significantly driven by second-round effects via inflation.

${ }^{15}$ Under fiscal stress, however, government and manufacturing wages tend to be better aligned when the public sector is relatively large (see Table 4). 


\section{Appendix}

Table 6 List of variables

\begin{tabular}{|c|c|c|}
\hline Variable & Definition & Source \\
\hline $\begin{array}{l}\text { Nominal compensations per employee } \\
\text { in the general government }\end{array}$ & $\begin{array}{l}\text { Calculated as the ratio of government } \\
\text { final wage consumption expenditures } \\
\text { (CGW) to government employment (EG) }\end{array}$ & OECD Economic Outlook \\
\hline $\begin{array}{l}\text { Real compensations per employee in } \\
\text { the general government }\end{array}$ & $\begin{array}{l}\text { Deflated by the price deflator of GDP } \\
\text { at market prices }\end{array}$ & AMECO \\
\hline $\begin{array}{l}\text { Nominal compensations per employee } \\
\text { in the manufacturing sector }\end{array}$ & $\begin{array}{l}\text { Calculated as the ratio of total } \\
\text { compensations of employees } \\
\text { to total employees in the } \\
\text { manufacturing industry }\end{array}$ & Eurostat \\
\hline $\begin{array}{l}\text { Real compensations per employee } \\
\text { in the manufacturing sector }\end{array}$ & $\begin{array}{l}\text { Deflated by price deflator of } \\
\text { gross value added in the } \\
\text { manufacturing industry }\end{array}$ & AMECO \\
\hline Productivity & $\begin{array}{l}\text { Gross value added at } 2005 \\
\text { prices per person employed }\end{array}$ & Eurostat \\
\hline Consumer price index & $\begin{array}{l}\text { National consumer price index } \\
\text { for all items }\end{array}$ & AMECO \\
\hline Unemployment rate & Standardized unemployment rate & Eurostat \\
\hline Government sector size & $\begin{array}{l}\text { Ratio of general government } \\
\text { to total employment }\end{array}$ & OECD Economic Outlook \\
\hline
\end{tabular}

\section{Acknowledgements}

We thank Alfonso Arpaia and Pedro Cardoso for the useful comments and discussions and as the anonymous referee and editor for the helpful remarks.

Responsible editor: Martin Kahanec

\section{Competing interests}

The IZA Journal of European Labor Studies is committed to the IZA Guiding Principles of Research Integrity. The authors declare that they have observed these principles.

\section{Disclaimer}

The views expressed in this paper do not reflect necessarily those of the European Commission.

\section{Author details}

${ }^{1}$ Department of Economics and Statistics, University of Udine, Via Tomadini 30/A, 33100 Udine, Italy. ${ }^{2}$ European Commission and IZA, Brussels, Belgium.

Received: 9 September 2016 Accepted: 16 December 2016

Published online: 30 January 2017

\section{References}

Afonso A, Gomes P (2014) Interactions between private and public sector wages. J Macroecon 39(A):97-112

Alesina A, Ardagna S, Perotti R, Schiantarelli F (2002) Fiscal policy, profits, and investment. Am Econ Rev 92(3):571-589

Alesina A, Perotti R (1997) The welfare state and competitiveness. Am Econ Rev 87:921-939

Algan Y, Cahuc P, Zylberberg A (2002) Public employment and labour market performance. Econ Policy 17:7-66

Ardagna S (2004) Fiscal stabilizations: when do they work and why. Eur Econ Rev 48:1047-1074

Ardagna S (2007) Fiscal policy in unionised labour markets. J Econ Dyn Control 31(5):1498-1534

Barrios S, Langedijk S (2010) Fiscal consolidations with external imbalances. In: Barrios S, Deroose S, Langedijk S, Pench

$\mathrm{L}$ (eds) External Imbalanced and Public Finances in the EU, European Economy, Occasional Paper 66., pp 99-119

Blanchard O (2007) Adjustment within the euro. The difficult case of Portugal. Port Econ J 6(1):1-21

European Commission (2014) Government wages and labour market outcomes, European Economy, Occasional Paper 190

Forni L, Giordano R (2003) Employment in the public sector, CESlfo Working Paper 1085

Giordano R et al (2011) The public sector pay gap in a selection of Euro area countries, ECB Working Paper 1406

Granger CWJ, Lee TH (1989) Investigation of production, sales and inventory relationships using multicointegration and non-symmetric error correction models. J Appl Econ 4:145-159

Hartog J, Oosterbeek H (1993) Public and private sector wages in the Netherlands. European Economic Review 37 (1): 97-114 
Holmlund B (1993) Wage setting in private and public sectors in a model with endogenous government behavior. European Journal of Political Economy 9(2):149-162

Holm-Hadulla F et al (2010) Public wages in the euro area: towards securing stability and competitiveness, ECB Occasional Paper 112

Jackman R, Layard R, Nickell S (1992) Unemployment. Oxford University Press, Oxford

Lamo A, Perez JJ, Schuknecht L (2013) Are government wages interlinked with private sector wages. J Policy Model 35(5):697-712

Lamo A, Perez JJ, Schuknecht L (2012) Public or private sector wage leadership? An international perspective? Scand J Econ 114(1):228-244

Lamo A, Perez JJ, Schuknecht L (2007) The cyclicality of consumption, wages and employment of the public sector in the euro area, ECB Working Paper 757

Lane P, Perotti R (2003) The importance of composition of fiscal policy: evidence from different exchange rate regimes. J Public Econ 87(9-10):2253-2279

Lane P, Perotti R (1998) The trade balance and fiscal policy in the OECD. Eur Econ Rev 42:887-895

Maffezzoli M (2001) Non-Walrasian Labor Markets and Real Business Cycles. Review of Economic Dynamics 4(4):860-892

Perez JJ, Sanchez-Fuentes AJ (2011) Is there a signaling role for public wages? Evidence for the euro area based on macro data. Empir Econ 41(2):421-445

Perotti R (1996) Fiscal consolidation in Europe: composition matters. Am Econ Rev 86(2):105-110

Submit your manuscript to a SpringerOpen ${ }^{0}$ journal and benefit from:

- Convenient online submission

- Rigorous peer review

- Immediate publication on acceptance

- Open access: articles freely available online

- High visibility within the field

- Retaining the copyright to your article

Submit your next manuscript at $>$ springeropen.com 